Volume : 6

Nomor : 2

Bulan : Mei

Tahun : 2020

URL: jurnal.ideaspublishing.co.id

\title{
Strategi Marketing melalui Online Travel Agent \\ dalam Meningkatkan Tingkat Hunian Kamar di Training Center Damhil \\ Universitas Negeri Gorontalo
}

\author{
Poppy Arnold Kadir \\ Universitas Negeri Gorontalo \\ Pos-el: poppykadir76@gmail.com
}

DOI: 10.32884/ideas.v\%vi\%i.276

\begin{abstract}
Abstrak
Penelitian ini bertujuan untuk mendeskripsikan strategi marketing melalui kerja sama dengan online travel agent dalam meningkatkan tingkat hunian kamar di Training Center Damhil Universitas Negeri Gorontalo. memiliki dampak yang cukup baik terhadap jumlah tingkat hunian tamu di Training Center Damhil. Metode yang digunakan yaitu kualitatif deskriptif. Teknik pengumpulan data dalam penelitian ini menggunakan wawancara, observasi, dokumentasi, dan studi pustaka. Teknik analisis data dalam penelitian ini dilakukan dengan cara (1) mengidentifikasi masalah yang terdapat pada strategi marketing melalui OTA di TC Damhil, (2) mengklarifikasi, (3) menganalisis, (4) mendeskripsikan, dan (5) menyimpulkan berbagai data yang diperoleh. Hasil penelitian menunjukkan bahwa kerja sama dengan online travel agent memiliki dampak yang cukup baik terhadap jumlah tingkat hunian tamu di Training Center Damhil. Tamu dapat secara langsung memberikan pendapat mengenai tempat menginap selama mereka tinggal. Hasil dari persepsi wisatawan yang akan diperoleh dari indikator-indikator yang ada di dalam TripAdvisor seperti nama dan alamat hotel, foto, lokasi, fasilitas, tanya jawab, tipe kamar, dan tampilan harga yang kemudian akan mempengaruhi keputusan wisatawan dalam memilih tempat menginap atau hotel. Ketika harapan atau ekspektasi wisatawan sesuai dan bahkan lebih dari yang diharapkan, maka tamu akan menuliskan atau membuat ulasan baru tentang pengalaman mereka selama menginap di dalam trip-advisor yang nantinya akan memberikan sitmulus bagi tamu berikutnya yang akan datang. Dengan strategi marketing yang dilakukan oleh manajemen Training Center Damhil dapat terlihat jumlah tamu yang menginap pada bulan-bulan yang biasanya sepi tidak ada tamu, mulai terisi dengan tamu yang melakukan reservasi melalui online travel agent.
\end{abstract}

Kata kunci: strategi marketing, online travel agent

\section{Pendahuluan}

Pariwisata merupakan salah satu sektor penting di Indonesia, terutama berperan dalam memberikan kontribusi terhadap peningkatan devisa negara. Pariwisata juga mampu meningkatkan pendapatan suatu daerah di Indonesia, tentunya setiap daerah yang memiliki daya tarik tersendiri mulai dari daya tarik objek wisata, budaya, adat istiadat, dan potensi wisata lainnya. Salah satu poin yang berkaitan dengan industri pariwisata adalah hotel. Hotel

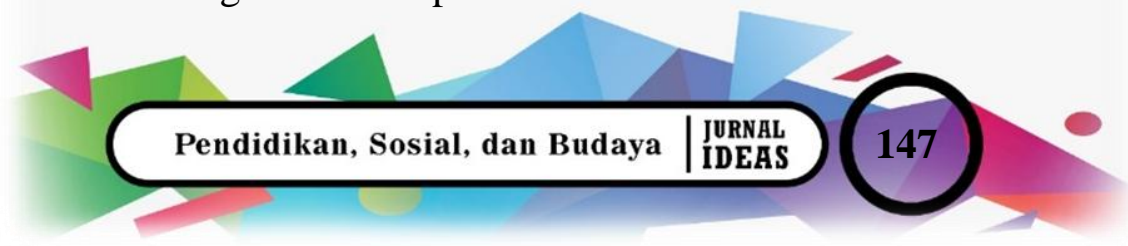




\begin{tabular}{|c|c|}
\hline F & Volume : 6 \\
\hline 6TK & $\begin{array}{ll}\text { Nomor } & : 2 \\
\text { Bulan } & : \text { Mei }\end{array}$ \\
\hline URL: jurnal.id & Tahun \\
\hline
\end{tabular}

merupakan akomodasi komersil yang sangat pesat perkembangannya di Indonesia (dalam Sulistiyono, 2011, hlm. 6).

Hotel menurut para ahli dikutip dari Sulistyono, (2006, hlm. 11) dalam hotel proprietor act adalah suatu fasilitas akomodasi yang dikelola dengan tujuan komerrsil yang menyediakan fasilitas kamar, makanan, dan minuman serta ruang meeting yang disewakan kepada orang yang sedang melakukan perjalanan dan mampu membayar dengan jumlah yang wajar sesuai dengan pelayanan yang diterima tanpa adanya perjanjian khusus.

Salah satu hotel yang berada di Kota Gorontalo adalah Training Center Damhil Universitas Negeri Gorontalo. Training Center dapat diartikan dalam kamus besar bahasa Indonesia sebagai balai pelatihan yang di dalamnya terdapat unsur-unsur pendidikan yang seharusnya dirasakan langsung manfaatnya bagi masyarakat sekitar.

Training Center dapat diartikan dalam kamus besar bahasa Indonesia adalah sebuah balai pelatihan dimana di dalamnya terdapat unsur-unsur pendidikan yang seharunya dirasakan langsung manfaatnya bagi masyarakat sekitar dimana Training Center ini berada, di bawah naungan Universitas Negeri Gorontalo dalam pengawasan Badan Layanan Umum (BLU), Training Center unggul dalam segi visi dan misi dari sebuah Training Center atau Balai Pelatihan, hal ini tentu saja dapat langsung dirasakan oleh masyarakat khususnya di Kota Gorontalo dan Provinsi pada umumnya.

Dari Wikipedia, arti training atau pelatihan yaitu proses melatih, kegiatan atau pekejaan. Maksud dari adanya pelatihan sendiri digunakan untuk mempersiapkan peserta latihan dalam mengambil jalur tindakan tertentu yang dilukiskan oleh teknologi dan organisasi tempat bekerja, dan membantu peserta memperbaiki prestasi dalam kegiatanya terutama dalam bidang pengertian dan keterampilan. Di dalam dunia pekerjaan, training ini menjadi sarapan pada saat mengawali pekerjaan. Arti training bagi perusahaan yaitu untuk meningkatkan kualitas dan keterampilan kerja karyawan.

Arti training pelatihan kerja menurut PP Nomor 31 Tahun 2006 tentang sistem pelatihan kerja nasional, arti training atau pelatihan kerja seluruh kegiatan untuk memberi, memperoleh, serta meningkatkan kompetensi kerja, produktivitas, disiplin, sikap, dan etos kerja pada tingkat keterampilan dan keahlian tertentu sesuai dengan jenjang dan kualifikasi jabatan dan pekerjaan. Dengan diadakanya pelatihan, peserta lebih terlatih dalam hal pengetahuan, keterampilan, dan sikap. 


$\begin{array}{ll}\text { Volume } & : 6 \\ \text { Nomor } & : 2 \\ \text { Bulan } & : \text { Mei } \\ \text { Tahun } & : 2020\end{array}$

\section{E-ISSH: 2656-940X 굴 P-ISSH: 2442-367X \\ URL: jurnal.ideaspublishing.co.id}

Training Center Damhil ini berada di bawah naungan Universitas Negeri Gorontalo dalam pengawasan Badan Layanan Umum (BLU), Training Center Damhil unggul dalam segala visi dan misi sebagai tempat pelatihan yang mumpuni. Hal ini tentunya saja dapat langsung dirasakan oleh masyarakat khususnya di Provinsi Gorontalo. Training Center Damhil mampu mensejajarkan dengan hotel berbintang yang ada di Kota Gorontalo. Kesejajaran ini salah satunya dapat dilihat dari jumlah kamar yang tersedia di Trainning Center Damhil. Berikut diuraikan satu per satu jumlah kamar hotel berbintang yang ada di Kota Gorontalo pada tahun 2018.

Tabel 1. Data Jumlah Kamar Hotel Berbintang di Kota Gorontalo Tahun 2018

\begin{tabular}{llccc}
\hline No. & $\begin{array}{c}\text { Hotel } \\
\text { Bintang }\end{array}$ & Jumlah Kamar & Tingkat Hunian & $\begin{array}{c}\text { Harga Rata-Rata } \\
\text { Kamar }\end{array}$ \\
\hline 1. & Maqna & 176 & $89.67 \%$ & 447.544 \\
\hline 2. & Grand Q & 124 & $49.07 \%$ & 434.558 \\
\hline 3. & Amaris & 90 & $48.94 \%$ & 349.920 \\
\hline 4. & TC Damhil & 42 & $14.41 \%$ & 657.143 \\
\hline \multicolumn{2}{l}{ Sumber Data: Olahan BPS Tahun 2018} & &
\end{tabular}

Berdasarkan data di atas, perkembangan hotel di Kota Gorontalo dituntut untuk meningkatkan kreativitas dan memanfaatkan segala kemajuan teknologi dengan segala cara agar dapat menarik minat tamu sebanyak-banyaknya. Strategi marketing yang dilakukan oleh hotel pada saat ini adalah direct selling, sales call, offline travel agent maupun melalui Online Travel Agent (OTA). Dengan adanya Online Travel Agent tamu dengan lebih mudah memiliki banyak pilihan dan kebutuhan yang sesuai dengan keinginan dan kemampuan pelanggan.

Perkembangan zaman semakin memudahkan dalam beraktivitas, kemudian menjadikan segala sesuatu menjadi cepat dan memotong waktu untuk menjadi lebih pendek. Kebutuhan baru muncul di segala aspek kehidupan, salah satunya adalah kebutuhan akan kepraktisan. Hal inilah yang selalu menjadi bisnis konvensional berevolusi ke arah ranah digital, untuk mengembangkan pangsa pasarnya secara lebih luas lagi. Hal tersebut juga terjadi dalam bisnis travel, kemajuan zaman membuat orang ingin bisa memenuhi persiapan perjalanan agar lebih cepat dan mudah. Pada saat ini tamu dapat memanfaatkan Online Travel Agent (OTA).

Online Travel Agent (OTA) adalah agen perjalanan yang berperan sebagai media promosi dan penjualan secara online melalui website yang dikelola oleh Online Travel Agent 


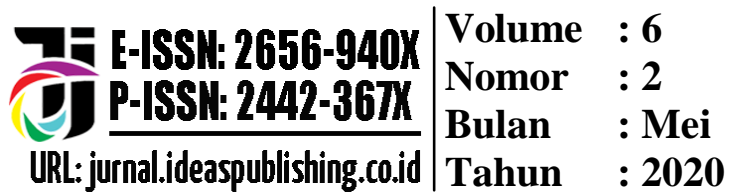

yang mendistribusikan dan memfasilitasi pemesanan ke pihak penyedia usaha pariwisata (Australian Tourism Data Warehouse, 2013).

Jenis pembayaran Online Travel Agent terbagi menjadi 2 yaitu: Online Travel Agent dengan quarantee payment adalah travel agent online. Pelanggan atau tamu yang memesan hotel harus membayar penuh kepada pihak OTA sebelum mendapatkan hotel voucher, sehingga pembayaran hotel merupakan tanggung jawab pihak OTA. Apabila terjadi pembatalan pemesanan, hotel tidak dirugikan karena masih memungkinkan penarikan pembayaran dari OTA sesuai pejanjian. Kedua, Online travel agent non quarantee payment yaitu travel agent online yang tidak mewajibkan pelanggan atau tamu untuk membyar terlebih dahulu, sehingga tamu atau pelanggan yang sudah teregistrasi sudah langsung bisa mendapatkan voucher hotel. Kelemahan model pembayaran yang kedua ini adalah bila pelanggan membatalkan pemesanan sewaktu-waktu terutama pada hari-H atau bahkan no show, hotel tidak dapat menarik pembayaran kepada pihak OTA atau tamu (lost business).

Menurut perjanjian antara hotel dengan perusahaan online travel agent dalam operasionalnya dapat dibagi dua, yaitu: B2B dan B2C. B2B (business to business) yaitu transaksi secara elektronik objek bisnis yang satu ke objek bisnis yang lainnya, kesimpulan B2B yaitu transaksi secara elektornik objek bisnis yang satu ke objek bisnis yang lainnya. B2C (Business to Consumen) adalah kegiatan E-business dalam pelayanan secara langsung kepada konsumen melalui barang atau jasa. Dengan penjualan langsung di internet dan pemesanan dapat langsung dilakukan oleh konsumen karena biaya sudah tercantum.

Pada dasarnya Online Travel Agent memiliki lingkup bisnis layaknya travel agent konvensional. Hanya saja online travel agent layanannya berbasis digital, yaitu layanan yang menggunakan transaksi layanan informasi, jual beli, dan pembayaran terjadi melalui online. Travel agent menyediakan berbagai pelayanan pada konsumen termasuk pembelian tiket pesawat dan reservasi hotel, membuat jadwal rencana perjalanan wisata juga memberikan informasi akurat terkait produk jasa yang akan dibeli oleh konsumen.

Daily Social telah melakukan survei yang bertujuan mengukur pola konsumsi Indonesia terhadap layanan OTA. Survei ditanyakan kepada 2013 responden melalui JakPat Mobile Survey Platform pada Februari 2018. Responden disampel secara proporsional terhadap populasi penduduk Indonesia sebanyak 71,44 \% responden pernah menggunakan OTA untuk keperluan reservasi hotel dalam enam bulan terakhir, antara 50-70 \% responden menggunakan Traveloka dan Tiket.com untuk mereservasi hotel sebanyak 83,95\% responden 


$\begin{array}{ll}\text { Volume } & : 6 \\ \text { Nomor } & : 2 \\ \text { Bulan } & : \text { Mei } \\ \text { Tahun } & : 2020\end{array}$

\section{E-ISSH: 2656-940X 들 P-ISSH: 2442-367X \\ URL: jurnal.ideaspublishing.co.id}

menggunakan smartphone untuk mengakses layanan OTA, dan $69.26 \%$ melakukan pembayaran terhadap layanan OTA melalui transfer rekening bank/ATM. Data ini memperlihatkan adanya wacana kemudahan dan keunggulan yang ditawarkan Online Travel Agent bagi konsumen berbanding lurus dengan meningkatnya tantangan yang dihadapi oleh marketing hotel.

Oleh karena itu, dalam meningkatkan tingkat hunian kamar Training Center Damhil mengubah strategi konvensional menjadi strategi marketing berbasis online seiring dengan perkembangan teknologi yang berkembang saat ini. Tingkat hunian kamar (Occupancy Presentage) dihitung dengan membagi jumlah kamar yang di pakai selama periode tertentu (misalnya satu malam atau satu minggu) dengan jumlah kamar yang tersedia selama periode yang sama dan dikalikan dengan 100. Sebagai contoh, apabila sebuah hotel memiliki 100 kamar, di mana 80 kamar di antaranya di huni selama satu malam, maka occupancy perrsentage malam tersebut adalah: $80 / 100 \times 100=80 \%$. Occupancy persentage yang tinggi sangat di inginkan oleh para pengelola hotel karena angka-angka ini menunjukan tingkat pemanfaatan fasilitas kamar yang tinggi, termasuk fasilitas-fasilitas hotel lainnya. Informasi kecenderungan angka ini merupakan informasi yang penting.

Marketing Manajer Damhil kini fokus utamanya pada testimoni konsumen di Online Travel Agent yang merupakan alat komunikasi pemasaran paling efektif dalam meningkatkan tingkat hunian kamar. Konsumen yang melakukan booking kamar melalui Online Travel Agent memiliki akses penuh untuk memberikan review terhadap hotel pilihan sesuai dengan pengalaman yang konsumen rasakan. Artinya, baik pengalaman positif maupun negatif dapat mereka sampaikan sebagai testimoni tanpa terkecuali. Hasil rate dan review tersebut, kemudian digunakan oleh beberapa Online Travel Agent seperti Traveloka.Com, PegiPegi.Com, dan booking.com. Hal ini untuk menentukan ranking hotel di onlline travel agent mereka. Kondisi inilah yang tentu harus menjadi perhatian departemen marketing secara cermat dan cepat. Dengan adanya respon negatif maupun positif dari konsumen merupakan penentu kebijakan bagi manajemen untuk meningkatkan strategi pemasaran di Training Center Damhil UNG.

Pemasaran merupakan salah satu kegiatan pokok dari badan usaha untuk dapat melaksanakan kegiatan usahanya demi kelangsungan hidup badan usaha. Pencapaian tujuan bisnis tidak hanya pada pemasaran saja, melainkan juga meliputi kegiatan produksi, 


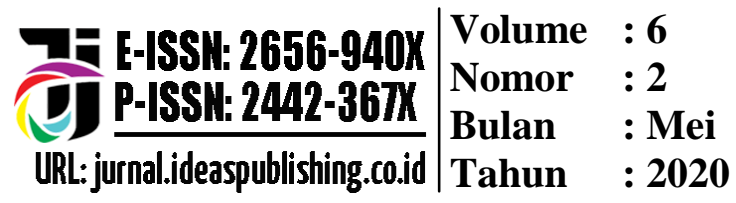

keuangan, serta bidang yang lain, oleh sebab itu kemampuan pengusaha untuk mengkombinasikan fungsi-fungsi tersebut sangat diperlukan agar suatu organisasi dapat berjalan dengan lancar. Menurut Kotler (2008:10) adalah sebagai berikut: "Marketing is a social and managerial process by which individuals and groups obtain what they need and want through creating, offering, and exchanging products of value with others."

Ada beberapa ahli yang mengemukakan pendapat mengenai bauran pemasaran, salah satu diantaranya adalah Kotler (2008:98) adalah sebagai berikut.

'Marketing mix is the set of marketing tools that the firm uses to persue its marketing objectives in the target market". Artinya, bauran pemasaran adalah salah satu alat penting untuk mencapai tujuan badan usaha. Program pernasaran yang baik harus dapat memadukan sernua elemen dari bauran pemasaran kedalam suatu program yang dapat mendukung tercapainya tujuan badan usaha.

Strategi pemasaran yang digunakan perusahaan sering pula disebut bauran pemasaran (marketing mix). Menurut Buchari Alma dalam Wisnawan (2012, hlm. 139), ada empat komponen yang tercakup dalam kegiatan marketing mix ini yang dikenal dengan sebutan $4 \mathrm{P}$ yang terdiri dari Product, Price, Place, dan Promotion. Menurut Kotler (2007, hlm. 92) bauran pemasaran adalah sejumlah alat-alat pemasaran yang digunakan perusahaan untuk meyakinkan objek pemasaran atau target yang dituju.

\section{Metode}

Metode yang digunakan yaitu kualitatif deskriptif. Teknik pengumpulan data dalam penelitian ini menggunakan wawancara, observasi, dan dokumentasi. Teknik analisis data dalam penelitian ini dilakukan dengan cara (1) mengidentifikasi masalah yang terdapat pada strategi marketing melalui OTA di TC Damhil, (2) mengklarifikasi, (3) menganalisis, (4) mendeskripsikan, dan (5) menyimpulkan berbagai data yang diperoleh. Data yang didapatkan secara keseluruhan akan dianalisis secara reduksi guna mendapatkan simpulan. Menurut Sutopo dan Arieff (dalam Ali 2015) reduksi data merupakan salah satu teknik analisis data kualitatif. Reduksi data adalah bentuk analisis yang menajamkan menggolongkan, mengarahkan, membuang yang tidak perlu dan mengorganisasi data sedemikian rupa 


$\begin{array}{ll}\text { Volume } & : 6 \\ \text { Nomor } & : 2 \\ \text { Bulan } & : \text { Mei } \\ \text { Tahun } & : 2020\end{array}$

\section{E-ISSH: 2656-940X 근 P-ISSH: 2442-367K URL: jurnal.ideaspublishing.co.id}

sehingga kesimpulan akhir dapat diambil. Upaya mendapatkan data dalam penelitian ini adalah dengan melakukan pengamatan (observasi), dokumentasi, dan wawancara. Wawancara yang dilakukan dengan metode wawancara terbuka dengan pihak pimpinan departemen marketing baik marketing manager maupun staf marketing di Training Center Damhil Universitas Negeri Gorontalo.

\section{Hasil dan Pembahasan Hasil}

Training Center Damhil Universitas Negeri Gorontalo adalah salah satu akomodasi yang dimiliki oleh unit bisnis kampus UNG, akomodasi ini dibangun dan diperuntukan untuk perluasan laboratorium Jurusan Pariwisata yang sebelumnya yaitu laboratorium Jambura Inn. Training Center Damhil terletak di Komplek Kampus Universitas Negeri Gorontalo. Saat ini TC Damhil memiliki 42 kamar, 2 kamar suite, 6 kamar deluxe, dan 34 kamar superior, beberapa ruang meeting diantaranya Ballroom I, Ballroom II, Ketapang, Jambura, Mahoni. Training Center Damhil juga memiliki 1 Barelo Resto dan 1 Key Coffee House.

Training Center Damhil UNG ini mulai beroperasi pada tahun 2015 dan diresmikan oleh Presiden Jokowi Widodo. Fasilitas dan pelayanan yang dimiliki sama dengan pelayanan hotel bintan tiga (***), karyawan yang dimiliki adalah $60 \%$ merupakan alumni Universitas Negeri Gorontalo dari berbagai jurusan sesuai dengan kompetensi yang dibutuhkan.

Awalnya tamu-tamu yang menginap di Training Center Damhil UNG merupakan tamu UNG sendiri yang merupakan tamu internal kampus. Namun seiring dengan berjalan waktu, TC Damhil mampu bersaing dengan hotel bintang lainnya yang ada di Kota Gorontalo seperti Hotel Maqna, Grand Q, dan Hotel Amaris yang merupakan hotel yang memiliki fasilitas yang cukup lengkap di Gorontalo. Saat ini, event meeting yang dilaksanakan di Training Center Damhil bukan hanya kalangan UNG namun dari dinasdinas pemerintah maupun pihak swasta yang menjadikan Training Center Damhil semakin dikenal sebagai pelayan akomodasi yang memiliki tingkat pelayanan layaknya hotel bintang.

Seiringnya waktu, banyak hotel yang mulai menjamur di kota Gorontalo baik hotel bintang maupun melati, sehingga persaingan di dunia industri perhotelan pun semakin ketat. Training Center Damhil mulai membuat strategi marketing dengan 


\begin{tabular}{|c|c|}
\hline F & Volume : 6 \\
\hline 6TK & $\begin{array}{ll}\text { Nomor } & : 2 \\
\text { Bulan } & : \text { Mei }\end{array}$ \\
\hline URL: jurnal.id & Tahun \\
\hline
\end{tabular}

memanfaatkan media online yaitu melalui Online Travel Agent yang sudah dikenal di Indonesia. Hal ini dikarenakan semakin majunya teknologi, sehingga pemesanan kamar melalui media online pun semakin mudah. Dulu, tamu agak kesulitan untuk mencari referensi hotel yang ada di daerah mapun negara tertentu. Tamu harus melakukan reservasi melalui telepon maupun walk-in (tamu melakukan reservasi kamar dengan datang langsung ke hotel). Namun, sekarang tamu dapat memilih jenis hotel, harga hotel sesuai dengan kebutuhan dan keinginan tamu. Reservasi kamar melalui Online Travel Agent memudahkan tamu untuk melihat guest review tamu yang menginap di hotel tersebut, sehingga tamu bisa dengan mudah untuk menentukan dimana tamu tersebut akan menginap.

Pada tahun 2015-2017 TC damhil belum bisa melakukan kerja sama dengan Online Travel Agent dikarenankan nama Training Center Damhil bukan sebagai "Hotel" hal ini menyebabkan tamu ragu dengan nama yang tercantum di OTA tersebut. Saat itu, TC Damhil pun belum mampu melengkapi fasilitas-fasilitas lain yang dapat dijadikan produk yang menarik untuk dijual. Pada saat itu Traning Center Damhil hanya fokus pada tamu internal kampus UNG, tamu goverment maupun corporate yang ada di luar lingkungan Universitas Negeri Gorontalo.

Pada awal tahun, tepatnya pada saat Januari-Maret occupancy (tingkat hunian kamar) Training Center Damhil sangat rendah, sehingga mengakibatkan biaya operasional yang ditanggung oleh Training Center Damhil pada bulan tersebut sangat berat karena hanya mengandalkan tamu-tamu lokal saja, sehingga pada Juli 2018 Training Center Damhil mulai melakukan kerja sama dengan Online Travel Agent seperti Booking.com, Tiket.Com, Pegi-pegi, dan Traveloka. Hal ini dapat dilihat dari penjualan kamar Training Center Damhil melalui Online Travel Agent pada Januari - Desember 2018 berikut ini.

Tabel 2 penjualan kamar Training Center Damhil melalui Online Travel Agent pada Januari-Desember 2018

\begin{tabular}{lcc}
\hline \multicolumn{1}{c}{ Nama OTA } & $\begin{array}{c}\text { Room Sold } \\
\text { Jan - Juni }\end{array}$ & $\begin{array}{c}\text { Room Sold } \\
\text { Juli - Des }\end{array}$ \\
\hline Booking.Com & 55 & 52 \\
\hline Pegi.Pegi & - & 30 \\
\hline Tiket.Com & - & 14 \\
\hline Traveloka & - & 318 \\
\hline \multicolumn{1}{c}{ TOTAL } & $\mathbf{5 5}$ & $\mathbf{3 8 4}$ \\
\hline
\end{tabular}

Sumber: Data Olahan Peneliti, 2019 


$\begin{array}{ll}\text { Volume } & : 6 \\ \text { Nomor } & : 2 \\ \text { Bulan } & : \text { Mei } \\ \text { Tahun } & : 2020\end{array}$

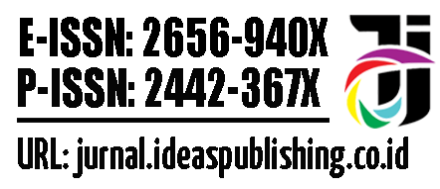

Berdasarkan tabel di atas penjualan kamar Training Center Damhil melalui OTA pada bulan Januari - July jumlah kamar yang terjual selama 6 bulan sebanyak 55 kamar. Hal ini disebabkan TC Damhil masih menggunakan 1 Online Travel Agent yaitu melalui Booking.com. sedangkan pada bulan Juli - Desember 2018 penjualan kamar TC Damhil meningkat menjadi 384 kamar. Penyebabnya adalah TC Damhil menambah kerja sama Online Travel Agent dengan Pegi.pegi, Tiket.com, dan Traveloka.

Kerja sama melalui Online Travel Agent memiliki dampak yang cukup baik terhadap jumlah tingkat hunian tamu di TC Damhil. Tamu dapat secara langsung memberikan pendapat mengenai tempat menginap selama mereka tinggal. Hasil dari persepsi wisatawan yang akan diperoleh dari indikator-indikator yang ada di dalam TripAdvisor seperti nama dan alamat hotel, foto, lokasi, fasilitas, tanya jawab, tipe kamar dan tampilan harga yang kemudian akan mempengaruhi keputusan wisatawan dalam memilih tempat menginap atau hotel. Ketika harapan atau ekspektasi wisatawan sesuai dan bahkan lebih dari yang diharapkan maka tamu akan menuliskan atau membuat ulasan baru tentang pengalaman mereka selama di dalam Trip-Advisor yang nantinya juga akan memberikan sitmulus bagi tamu yang akan datang berikutnya.

Dengan strategi marketing yang dilakukan oleh manajemen TC Damhil dapat terlihat jumlah tamu yang menginap pada bulan-bulan sepi mulai terisi dengan tamu-tamu yang melakukan reservasi melalui online travel agent. Pada tahun 2019, TC Damhil mulai melakukan keja sama dengan Tiket.com untuk kerja sama dalam bidang tiketing pesawat. Hal ini sangat menguntungkan bagi TC Damhil karena memiliki fasilitas pelayanan tiket pesawat melalui tiket.com. Berikut ditampilkan data jumlah total kamar yang dimiliki TC Damhil.

Tabel 3 Data Jumlah Total Kamar yang Terjual dan Tingkat Hunian Kamar pada Tahun 2018

\begin{tabular}{lcccc}
\hline BULAN & OTA & NON OTA & TOTAL & OCC (\%) \\
\hline Januari & 7 & 298 & 305 & 23,42 \\
\hline Februari & 14 & 717 & 731 & 62,15 \\
\hline Maret & 14 & 638 & 652 & 50,00 \\
\hline April & 16 & 687 & 703 & 33,33 \\
\hline Mei & 2 & 390 & 392 & 30,10 \\
\hline Juni & 2 & 122 & 124 & 9,84 \\
\hline Juli & 16 & 511 & 527 & 40,48 \\
\hline & & & & \\
& & & Pendidikan, Sosial, dan Budaya & |JRNAL \\
IDEAS
\end{tabular}




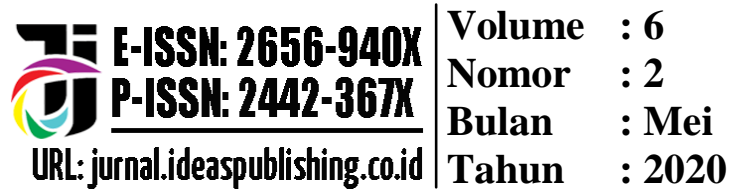

\begin{tabular}{lcccc}
\hline Agustus & 37 & 683 & 720 & 55,30 \\
\hline September & 58 & 635 & 693 & 55,00 \\
\hline Oktober & 68 & 483 & 551 & 42,32 \\
\hline November & 28 & 812 & 840 & 66,67 \\
\hline Desember & 50 & 808 & 858 & 65,90 \\
\hline TOTAL & $\mathbf{3 1 2}$ & $\mathbf{6 . 7 8 4}$ & $\mathbf{7 . 0 9 6}$ & $\mathbf{4 4 , 5 4}$ \\
\hline
\end{tabular}

Sumber: Hasil Olah Data Peneliti, 2019

Berdasarkan tabel di atas dapat dilihat bahwa jumlah penjualan kamar melalui OTA sebanyak 312 kamar atau sebesar 4,40 \% sedangkan jumlah penjualan kamar melalui NonOTA sebanyak 6.784 kamar atau sebesar 95,60\%. Hal ini dapat terlihat bahwa jumlah penjualan tamu yang terbesar di TC Damhil berasal dari Goverment maupun corporate yang berasal dari tamu lokal yang ada di Provinsi Gorontalo. Rata-rata tingkat hunian kamar pada tahun 2018 masih tergolong belum cukup baik yaitu sebesar 44,54\%. Dengan demikian pihak manajemen TC Damhil harus lebih meningkatkan penjualan melalui Online Travel Agent lain yang ada di Indonesia guna meningkatkan tingkat penjualan kamar tamu.

Berikut adalah data jumlah total kamar yang terjual dan tingkat hunian kamar pada tahun 2019.

Tabel 4 Data Jumlah Total Kamar yang Terjual dan Tingkat Hunian Kamar pada Tahun 2019

\begin{tabular}{lcccc}
\hline Bulan & OTA & NON OTA & TOTAL & OCC (\%) \\
\hline Januari & 25 & 365 & 390 & 29,95 \\
\hline Februari & 31 & 371 & 402 & 34,18 \\
\hline Maret & 28 & 1.066 & 1.094 & 84,02 \\
\hline April & 62 & 863 & 925 & 73,41 \\
\hline Mei & 24 & 643 & 667 & 51,23 \\
\hline Juni & 55 & 606 & 661 & 52,46 \\
\hline Juli & 66 & 659 & 725 & 55,68 \\
\hline Agustus & 99 & 542 & 641 & 49,23 \\
\hline September & 95 & 759 & 854 & 67,78 \\
\hline Oktober & 120 & 612 & 732 & 56,22 \\
\hline \multicolumn{1}{c}{ Total } & $\mathbf{6 0 5}$ & $\mathbf{6 . 4 8 6}$ & $\mathbf{7 . 0 9 1}$ & $\mathbf{5 5 , 4 1}$ \\
\hline
\end{tabular}

Berdasarkan tabel di atas dapat dilihat bahwa jumlah penjualan kamar melalui OTA sebanyak 605 kamar atau sebesar 8,54 \% sedangkan jumlah penjualan kamar melalui NonOTA sebanyak 6.486 kamar atau sebesar 91,46\%. Hal ini dapat terlihat bahwa jumlah penjualan tamu yang terbesar di TC Damhil masih berasal dari Goverment maupun 


$\begin{array}{ll}\text { Volume } & : 6 \\ \text { Nomor } & : 2 \\ \text { Bulan } & : \text { Mei } \\ \text { Tahun } & : 2020\end{array}$

\section{E-ISSH: 2656-940X 굴 P-ISSH: 2442-367K \\ URL: jurnal.ideaspublishing.co.id}

corporate yang berasal dari tamu lokal yang ada di Provinsi Gorontalo. Rata-rata Tingkat hunian kamar pada tahun 2019 sudah cukup meningkat menjadi 55,41\%.

Berdasarkan hasil dari penjualan kamar pada tahun 2018 tingkat hunian kamar sebesar $44.54 \%$ sedangkkan tingkat hunian kamar pada tahun 2019 menjadi $55.41 \%$ sehingga terjadi peningkatan tingkat hunian kamar yaitu sebesar 10,87 \%. Dengan demikian pihak manajemen TC Damhil harus lebih meningkatkan penjualan melalui OTA lain yang ada di Indonesia guna meningkatkan tingkat penjualan kamar tamu.

\section{Pembahasan}

Strategi pemasaran yang dilakukan oleh $T C$ Damhil dengan melakukan kerja sama dengan Online Travel Agent merupakan upaya yang dilakukan manajemen dalam meningkatkan tingkat hunian kamar tamu. Tetapi usaha lain dalam bentuk brosur, leaflet, maupun sales call tetap dijalankan guna mempertahankan loyalitas pelanggan. Produk utama yang dijual TC Damhil adalah sebagai berikut.

1) Kamar, jumlah kamar yang dimiliki oleh $T C$ Damhil berjumlah 43 kamar dengan tipe kamar Superior Room (33 kamar), Deluxe (5 kamar), dan Executive Suite (4 kamar).

2) Food and Beverage Outlet, TC Damhil UNG memiliki outlet BaReLo atau coffee shop yang digunakan sebagai tempat makan pagi, makan siang, dan makan malam bagi tamu. Kapasitas yang dimiliki 56 kursi dan mulai beroperasi 06.30 - 23.00 wita. Jenis makanan yang dijual adalah Indonesian Food dan Western Food. Selain BaReLo TC Damhil memiliki Key Coffee House, yaitu coffee house bagi tamu-tamu yang ingin menikmati musik karoeke. Makanan yang disajikan berupa light meal, coffee, dan jenis minuman lainnya. Food and beverage memiliki 6 function room yaitu Ballroom I, Ballroom II, Jambura, Mahoni, Ketapang dan Palm Room .

\section{Place}

Lokasi Training Center Damhill UNG terletak di Jalan Ir. H. Joesoef Dalie. Lokasi TC Damhil sangat strategis karena berada di Kota Gorontalo. Aksesibilitas sangat mudah dijangkau, hanya 5 menit dari pusat perbelanjan terbesar di Kota Gorontalo yaitu Citimall Gorontalo. 


\begin{tabular}{c|ll} 
E E-ISSH: 2656-940X & $\begin{array}{l}\text { Volume } \\
\text { Nomor }\end{array}$ & $: 2$ \\
PR-ISSH: 2442-367K & \\
Bulan & $:$ Mei \\
Tahnal.ideaspublishing.co.id & Tahun & $: 2020$
\end{tabular}

\section{Price}

TC Damhil UNG menerbitkan tarif kamar yang berbeda baik untuk pelanggan coorporate maupun untuk internal UNG. Penetapan tarif ini telah disepakati bersama antara pihak pengelola dan Badan Pengelola Usaha (BPU) yang kemudian disahkan pihak UNG untuk ditandatangi Rektor UNG selaku pimpinan BLU. Harga kamar yang ditetapkan telah disesuaikan dengan SBU yang berlaku, mengingat TC Damhil merupakan mitra pemerintah. Harga kamar yang telah ditetapkan dituangkan ke dalam SK Rektor Universitas Negeri Gorontalo No. 291/UN47/BU/2019 Tentang Penetapan Tarif Training Center Damhil UNG pada 18 Februari 2019. Berikut adalah Tipe dan Harga Kamar Training Center Damhil tahun 2018.

Tabel 5. Tipe dan Harga Kamar TC Damhil

\begin{tabular}{cll}
\hline Tipe Kamar & Harga Kamar Coorporate & \multicolumn{1}{c}{ Harga Kamar UNG } \\
\hline Superior & $\mathrm{Rp} 650.000$ & $\mathrm{Rp} 525.000$ \\
\hline Deluxe & $\mathrm{Rp} 950.000$ & $\mathrm{Rp} 750.000$ \\
\hline Executive & $\mathrm{Rp} 1.500 .000$ & $\mathrm{Rp} 1.200 .000$ \\
\hline Extra Bed & $\mathrm{Rp} 250.000$ & $\mathrm{Rp} 250.000$
\end{tabular}

Sumber : Training Center Damhil UNG, 2019

\section{Promotion (Produk)}

Cara promosi yang dilakukan Training Center Damhil UNG antara lain dengan promosi word of mouth, Mengikuti event-event tertentu, mengadakan diskon khusus pada saat tertentu, memberi member card pada pelanggan, dapat juga dilakukan melalui promosi reklame sisipan pada koran dan media massa atau menggunakan spanduk. Selain itu membuat konsep yang unik dan disukai oleh pelanggan.

Periklanan yaitu bentuk presentasi dan promosi non pribadi tentang ide, barang serta jasa yang dibayar oleh sponsor tertentu. Beberapa promosi yang dilakukan adalah melalui media cetak, yaitu manajemen melakukan kegiatan melalui coorporate social responsibily dengan bekerja sama baik dengan pemerintah maupun dengan masyarakat sekitar. Kegiatan ini diliput oleh media cetak yang ada di kota Gorontalo yaitu Gorontalo Post. Selain itu promosi mealui media periklanan yang ada di buku panduan pesawat citilink dengan pemberian discount bagi pengguna pesawat citilink ke Gorontalo.

Personal Selling yaitu presentasi lisan dalam suatu percakapan dengan satu calon pembeli atau lebih yang ditunjukan untuk menciptakan penjualan. Hal ini merupakan tugas 
$\begin{array}{ll}\text { Volume } & : 6 \\ \text { Nomor } & : 2 \\ \text { Bulan } & : \text { Mei } \\ \text { Tahun } & : 2020\end{array}$
E-ISSH: 2656-940K

P-ISSH: 2442-367K

URL: jurnal.ideaspublishing.co.id

dari bagian departemen marketing untuk melakukan promosi secara individu baik kepada kepala pemerintahan yang berwenang maupun kepada pemilik perusahaan swasta. Kegiatan personal selling ini tidak hanya dilakukan oleh departemen marketing tetapi oleh seluruh karyawan yang ada di Training Center Damhil.

Publisitas yaitu mendorong permintaan secara non-pribadi untuk suatu produk jasa atau ide dengan menggunakan berita komersial di dalam media massa atau sponsor yang tidak dibebani sejumlah bayaran secara langsung. Publisitas melalui media massa juga dilakukan oleh manajemen Training Center Damhil yaitu melalui koran maupun media sosial seperti Instagram, Facebook maupun melalui WA Story. Hal ini sangat efektif karena pihak manajemen mengeluarkan biaya marketing lebih sedikit dibandingkan harus mengeluarkan dana di media cetak.

Promosi juga dilakukan melalui penerbitan discount dalam upaya meningkatkan penjualan kamar. Berikut ini discount yang sudah pernah diterbitka.

\section{Flash Deal traveloka, Discount $20 \%$ from OTA Rate}

2. Early Bird Promo Traveloka, DisCount $20 \%$ from OTA Rate

3. Flash Deal Booking Direct, Special Room Rate Rp. 550.000,-

4. Ultimeght Tiket.Com Birthday, Discount $25 \%$ from OTA Rate

5. \#Epicsale At Traveloka, Discount 33\% from OTA Rate

6. Splash Deal At Tiket.Com, Discount 20\% from OTA Rate

7. \#Epihour At Traveloka, Discount 37\% from OTA Rate

8. Sweetember At PegiOPegi, Discount $20 \%$ from OTA Rate

Promosi lain yang dilakukan oleh Training Center Damhil yaitu dengan membuat akun instragram dengan nama TC Damhil UNG, yang berisi informasi mengenai promosi makanan, games, kegiatan meeting, kegiatan Corporate Sosial Responsibility, kegiatan kerja sama Training Center Damhil UNG dengan pemerintah maupun dengan sekolah SMK yang ada di kota Gorontalo, fasilitas kamar, fasilitas penunjang lainnya. Akun instagram memiliki 680 follower dan 1.122 following, melalui facebook, WA \& SMS Blast dengan 380 lebih kontak klien, dan guest email collection yang saat ini sudah terkumpul lebih dari 100 email.

Berdasarkan data yang peneliti peroleh, tamu Training Center Damhil memberikan review yang cukup baik terhadap fasilitas kamar yang telah digunakan, walaupun masih 


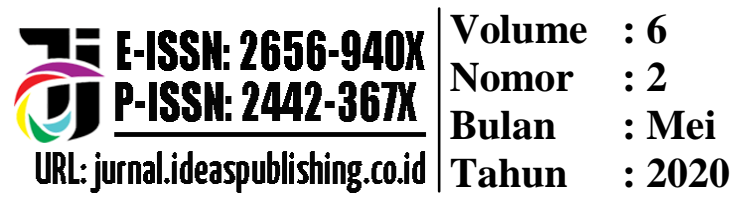

ada beberapa kekurangan terhadap review tamu. Kontribusi Online Travel Agent yang paling banyak adalah berasal dari traveloka. Hal ini dibuktikan Training Center Damhil UNG mendapatkan Certificate Excelent dari Tripadvisor pada tahun 2019 yaitu Training Center Damhil dinobatkan sebagai Akomodasi Terbaik nomor 1 dari 14 hotel yang ada di Gorontalo.

\section{Simpulan}

Berdasarkan dari hasil penelitian dan pembahasan di atas, maka dapat disimpulkan tiga hal. Pertama, strategi marketing yang dilakukan oleh Training Center Damhil dengan melalui Online Travel Agent sangat efektif dalam meningkatkan tingkat hunian kamar. Kedua, dengan meningkatkatnya tingkat hunian kamar, maka manajemen dapat meningkatkan tingkat revenue sehingga menguntungkan bagi pihak pengelola. Ketiga, dengan adanya review guest terbaik melalui TripAdvisor menambah nilai tamu untuk memutuskan tinggal di Training Center Damhil sebagai pilihan akomodasi terbaik di Kota Gorontalo.

\section{Daftar Pustaka}

Buchari, Alma. (2007). Manajemen Pemasaran dan Pemasaran Jasa. Edisi Revisi. Bandung: Alfabeta. Perhotelan

Budi, Agung. (2013). Manajemen Marketing. Andi Offset: Yogyakarta.

Kotler, Philip. (2008) Manajemen Pemasaran. Edisi 12 Jilid 2. Jakarta: Indeks., New Jersey.

Kotler, Philip. (2007). Manajemen Pemasaran, Jilid 2, Edisi 12, Indesks., New Jersey.

Simatupang, Violetta (2009). Pengaturan Hukum Kepariwisataan Indonesia. Alumni: Bandung.

Sugiyono. (2009). Metode Penelitian Bisnis. Alfabeta: Bandung.

Sulistioyono, Agus. (2006). Managemen Penyelenggaraan Hotel. Alfabeta: Bandung.

Sutopo (2006). Metodelogi Penelitian Kualitatif: Dasar teori dan Terapanya dalam Penelitian. Surakarta: Universitas Sebelas Maret.

Undang-Undang Nomor 9 tahun 2009 tentang Kepariwisataan.

SK Menhub RI No.PM 10/PW.391/PHB-77 tentang Hotel.

Kartajaya, Hermawan. (2007). Elemen Marketing on Marketing Mix. Penerbit: Mizan Pustaka: Bandung.

Nugroho, Setiadi J. (2003). Manajemen Pemasaran. Graha Ilmu: Yogyakarta.

Reid, Robert D., Bojanic, dan David C. (2010). Hospitality Marketing Management. Fifth edition. New Jersey: John Wiley and Sons, Inc.

https://binus.ac.id/malang/2017/10/online-travel-agent-sebagai-faktor-pendukung-danpenghambat-strategi-komunikasi-pemasaran-public-relations-hotel/

https://blog.citos.id/pengertian-tentang-online-travel-agent-ota-dan-jenis-travel-agen/

https://www.skyscanner.co.id/berita/11-online-travel-agent-mitra-skyscanner-indonesia 